\title{
EFFECTIVENESS OF TEACHERS' TRANSFORMATIONAL LEADERSHIP STYLE ON STUDENTS’ ACADEMIC ACHIEVEMENT
}

\author{
Syeda Nighat Firdous Bukhari ${ }^{*}$ \\ Sufiana Khatoon Malik ${ }^{* *}$
}

\begin{abstract}
The main aim of this research was to find out the effectiveness of teachers' transformational leadership styles on students' academic achievement. The objectives of the study were: to evaluate opinions of public and private sector college teachers about transformational leadership style, to assess difference of views about idealized influence, to judge difference of views about inspirational motivation, to appraise difference of views about intellectual stimulation, to consider difference of views about individual consideration and to compare relationship between teachers' transformational leadership style and students' academic achievement. The study involves the descriptive research methodology by using the standardized test 'Multifactor Leadership Questionnaires' (MLQ 5x-short) $3^{\text {rd }}$ edition developed by Bruce and Bernard (1994) to collect information. This questionnaire consists of two parts: the Self Rating Form, where leader/teacher rate themselves as leaders, and the Rater Form, where follower/student rates their leaders/teachers. Data was collected through personal visits to the sample comprising 605 students and 600 teachers of secondary classes in both public and private colleges. Analysis of data revealed no significant difference of opinion among public and private sector college teachers about transformational leadership style except their views on the intellectual stimulation and individual consideration. Similarly strong association was not found between the transformational leadership styles of teachers and students' academic achievement. This means teachers of private sector colleges have awareness about
\end{abstract}

\footnotetext{
* Lecturer, Department of Education, IMCG Postgraduate, Islamabad, Pakistan

** Assistant Professor, Department of Education, NUML Islamabad, Pakistan
} 
development of creative and critical thinking abilities of their students. The study recommends a need to create awareness among teachers in both sectors about how to perform according to set standards of the organization and to develop students' personalities.

Keywords: Academic achievement, Leadership, Teacher leadership styles, Transformational leadership.

\section{Introduction}

The study examines the effectiveness of teachers' transformational leadership style on students' academic achievement. Nowadays teachers' leadership in the classroom environment has gained importance and is the basic concern for developing the interest of researchers, policy makers, and educationists. There is no awareness about the effectiveness of this concept in our country. There is lack of research regarding teachers' leadership and its effectiveness. The main purpose of the study was to develop awareness among our teachers about the importance of this leadership style. The objectives of the study were: to evaluate opinions of public and private sector college teachers about transformational leadership style, to assess difference of views about idealized influence, to judge difference of views about inspirational motivation, to appraise difference of views about intellectual stimulation, to consider difference of views about individual consideration and to compare relationship between teachers' transformational leadership style and students' academic achievement. For achieving these objectives six null hypotheses were developed: There is no significant difference of opinions of public and private sector teachers about transformational leadership style: there is no significant difference of opinions of public and private sector college teachers' about idealized influence: there is no significant difference of opinions of public and private Sector college teachers about inspirational motivation: there is no significant difference of opinions of public and private sector teachers about intellectual stimulation: there is no significant difference of opinions of public and private Sector teachers about individual consideration: there is no significant relationship of teachers' transformational leadership style with students' academic achievement. 


\section{Literature Review}

The concept was first introduced by Burn (1978). According to his ideology this type of leader has some specific abilities like he develops motivation and enthusiasm in his followers to achieve their specific targets, develops their thinking abilities and a tendency to think beyond their personal needs. It was Bass (1978) who established this concept of leadership. He extended this concept and developed it into a very powerful conceptualization of a style of leaders. According to this idea, a leader performs his duties as an amiable and beloved personality for his followers and they want to obey his orders. Such leaders achieve their targets by enhancing motivational level of their followers and activating their responsiveness to achieve awareness. They increase their level of consciousness about the importance and value of targeted results and search novel ideas to reach them. Bloom, Hastings \& Madaus (1971) described transformational leadership as consisting of learners' thoughts and creativity that is important for achieving educational targets, improving their academic achievement, developing creativity, achieving new information and developing different abilities. Review of relevant literature supports this notion that students' learning depends upon their teachers' leadership styles. The research studies held in the field of education such as those conducted by Burns and Bass (1985) and Bass \&Leithwood (1994) explained this concept in educational environment and expounded that transformational leadership skills are necessary for achieving specific educational goals and improving academic levels of learners through active and positive performance.

Research literature on transformational leadership in recent years describes different outcomes of effective transformational leadership like cohesion, better performance, employee satisfaction, innovation, organizational commitment, and follower personality development in a variety of contexts e.g. military, corporate, emergency response, and a few in the educational sector. Islam (2012) conducted a research on impact of these leadership styles regarding motivation along with actions of students at university level and found that both styles have positive impact on students' performance. Bodla\& Nawaz (2010) found the same positive relationship between transformational leadership and learner achievement.

The recent studies conducted (Griffith, 2004; Jantzi et al., 2002) about the supervisors, showed that this type of leaders can enable them to 
achieve their employees' competency, satisfaction about their profession and high motivational level. As a result they reveal advance standards of institutional agreement. Bass (1985; 2008) discovered four important components about this style: idealized impact, individualized concern, rational motivation and inspiring enthusiasm. He explained that these leaders:

1. Encourage workers to achieve targets which exceed their personal requirements, they help their workers in identifying their own personal abilities; they direct their imagination and enable them to perform in a very flawless manner through inspiration.

2. Reject the traditional and conventional manners for performing their duties, they develop novel concepts plus improve confidence of their supporters to think on new tracks.

3. Make clear the concepts of their supporters and enhance their motivational level through inspiring them as being role model for them.

4. They are always ready to meet the requirements and personal needs of their supporters and workers by achieving their personal and organizational targets.

5. Their function is vital for developing their followers' personalities through creating a conducive environment.

The leaders having such leadership style create confidence, self-esteem and high regards in their supporters who are believed to be their chief support and recipient of their guidance. By acting upon these guidelines they can achieve beyond their personal abilities. About the positive effects of leaders' leadership style on their followers, Barling \& Iverson (2005) assert that these leaders by setting a personal example become very sensitive for achieving the organizational targets (idealized impact). They further explained that these leaders generate confidence, inspiration and encourage for their devotees to perform extra ordinarily and search novel ideas for tasks completion such as teacher leaders who motivate their students to solve their educational problems by creativity and searching new ways for achieving academic success. They are sincere about the life and safety for their workforce. They also exhibit optimistic concern for the security of their employees by ensuring equality and fulfillment of workers' institutional commitments through development of a healthy and secure environment.

In his research study Avolio (1989) cites some experimental evidences that maintain the concept, findings and vision of Bass (1998). He 
contends that the leaders' effectiveness is the basic aim of developing leadership abilities. He suggested that it should be communicated via his gestures, attitudes and performances as being a charismatic personality. Likewise, Bass (1990) suggests that charisma of transformational leaders should be represented by his behavior because this is the basic element in the personality of a transformational leader and that differentiates him from the transactional leader, as personality charm is also a basic and important element for this leadership style. In the words of Bass (1985), this gives birth to deep and exciting relationship among manager and his/her workers; this develops enthusiasm regarding tasks, specific projects and enhances their motivational level. This can be exhibited from the behavior of the leader through the responses of his workers/employees or followers in the form of their gestures, acceptance, confidence and their admiration for their leader. This admiration leads them to achieve their tasks appropriately and positively. Being an ideal personage and role model for his followers a transformational leader leads them by the very charm of his personality and his followers want to comply with his orders as their duty and they want to accept him as an authority. Through this important element of transformational leadership style and the idealized influence, the leader completes his targets by use of motivational language.

A research study held by Awamleh (2005) revealed that the behavior of leader can change the work capacity and condition of an employee. He put forth examples from different organizations like that of a local bank where the situation was overall changed because of the leadership style of its bank manager who changed the motivational level of his workers, because this style of leadership gives rewards in the form of workers' motivation, courage, confidence and trust on his leader. With the help of these factors an employee can face the hard realities of his life. Avolio (1990) declared that the respect or concern that leaders or the supervisors show toward their employees is always depicted from their personalities, work abilities, interest, their motivational level and performance. This can be seen from their final achievements or results like students' final results.

As Bass (1990) describes that it happens at the time when managers encourage and develop motivational level of workers, managers create consciousness about objectives and importance of collective cause. According to Barbuto (2005), it develops confidence, faith, respect, and devotion among the followers/students and workers of such 
leaders/teachers or managers. In their studies, Kelly, (2003) and Yukl (1989) after analyzing the leadership styles found out that these leaders raise life standard of their followers. According to their findings, this category of leaders provides courage and enhances the work ability of the workers for achieving specific goals. Cardona (2000) held a research study to assess the basic qualities of a transformational leader like and claimed that he encourages and motivates his supporters for communal trade and financial trade system by developing a balance management/ leadership system first in their organization and then in their country.

The transformational leaders use different styles and rewards/punishment according to the need of specific environment and according to the performances of their workers/students and followers. Sometimes they follow such styles like inspiring and motivating style but sometimes they become harsh and even punish their followers. All this is because of the demand of their current situation and performances of their followers. As Charbonneau(2004)) in his results of the study compares the leadership styles and concludes the transformational leaders generally follow different styles and behavior according to the demands of their field or situation taking into consideration the level of performances of their workers. The literature explained the fact that the style of leaders has complete power over the inner and outer level of inspiration of their workers and they become successful leaders as compared to other leaders. The foundational theme of this concept of leaders' style is the one in which the leader changes the current situation of an individual as well as the organization by his personal performance like a teacher who can change the overall situation and personalities of his students. Through coordination between a leader and his worker their specific tasks can be achieved with the help of different tactics like motivational language, inspiring them and by providing moral support and giving some rewards. Leithwood $(1994,2002)$ as result of his series of researches on transformational style developed a model with four important dimensions which are as under:

\section{Idealized influence (attributes and behaviors)}

According to this dimension people feel that their leader is an ideal person for them so they want to obey, follow and accept his directions to perform and achieve their targets. This dimension makes leaders a hero in the eyes of their workers/followers. Their followers tend to admire, respect and trust them. These leaders inculcate in their followers energy, sense of responsibility and a sense of fulfillment. They achieve these 
targets through developing a sense of devotion in their followers for their organization.

Bass and Riggio (2006) state that leaders are like heroes to their followers and they want to obey them follow and even imitate them as they are the role models for them. Additionally the researchers explained different concepts of this dimension regarding leaders' leadership styles' like: his attitude toward his followers and organization and such basics by which the followers identify him.

Transformational leaders with this dimension have ability to face the challenges. Their followers can trust them because they are reliable and dependable. They can share all problems with them very easily because these leaders are always willing to guide their followers to the right direction like a teacher leader who is always trying his best to solve his students' problems and strives for their betterment in their academic endeavors. The dimension is related with developing self-assurance and faith and makes the leader a hero for his followers and they want to obey his orders as they are duty bound to obey them. Followers have confidence in their leaders and they love them. Followers give value to them and this response from followers makes the leader a transformational leader because these elements are like base for creating true leadership and indirectly it is helpful for the progress of an organization. In the words of Gellis (2001), the dimension of idealized influence is totally based on charm of leaders' personality. This is a basic and important element of transformational leaders' style and acts like an association between the leader who has charisma of his personality and the followers who accept his characteristics.

\section{Individualized consideration}

This dimension deals with giving confidence to all workers, subordinates and students as they are an integral part of such organization and are important to it. It explains the phenomenon of the leader giving personal attention to all his followers individually. In the words of Simic (1998) ,according to this dimension leader extends personal response toward everyone, considering their personal needs and requirements and to motivate everyone to participate in the process of task completion. Simic (1998) examines that this dimension consists of completing the followers' basic requirements, motivating them and making sure that they can take part in the proper completion of task as well as in the progress of the organization while at the same time considering their 
individual differences and their abilities. In other words we can say that follower can be changed if the leader wants to change him like a true transformational leader changes the whole situation of the follower, for example by changing and developing his motivational level that is helpful in accomplishing followers' specific task properly.

\section{Inspirational motivation}

According to this concept a transformational leader inspires his followers and the whole organization exerting the charisma of his personality. A leader having transformational skills motivates his followers, develop the ability to see the world in new perspective, work with enthusiasm and develop the ability to face the challenges of this newly created world. This dimension helps the leader to complete all his duties and followers accept all his orders by getting inspiration from his personality and his personal charm which is called inspirational motivation. The leader is by the side of his followers to support him as the important component of the whole organization. According to Bass (1988), this dimension is the ability of a leader to communicate in a very flexible way with the purpose of achieving the individual as well as the organizational targets. It is a capability for developing the mutual consideration about the task and developing the concept of what is good or bad for the organization. They provide understanding of possibilities for attaining targets. A leader through this dimension increases followers' awareness and encourages them for achieving constructive expectations.

\section{Intellectual stimulation}

According to this concept, a leader develops awareness, creativity, knowledge, and thinking power of his followers and through these skills they can develop awareness and can be able to face the challenges and handle all troubles that are hindering their way of tasks completion. According to Bass and Avolio (1999), this dimension is connected with imagination and novelty and thinking ability of the followers. With the help of this dimension, the leader assists them by solving their troubles in novel and innovative styles. Leader also develops confidence in them by polishing their attitude, value, standards and principles whenever it is suitable and better for their personal well being. It is an integral element for seeking knowledge and for developing the critical thinking ability among them, which is important to the resolution of their issues without any help. With this ability they can search for new ways of resolving their problems. Russell (2003) expressed the same opinion when he 
asserted that leader with the help of intellectual stimulation can remove the fear of hurdles for developing new concepts for achievement of their specific targets. Bass (1985) insists that when leader removes the fear of his followers, they also realize and remove the basic hurdles in the course of development of their organization. They make it clear what and how many chances and opportunities are available to them for the progress of their organization. They point out their specific powers and available advantages. As Barbuto (2005) described that these leaders develop the sense of faith and confidence in their followers like a teacher leader develops the personalities of his students and develops power to handle and overcome the troubles of their educational process. On the same lines, Simic, (2003) while exploring the leadership effectiveness exclaimed that followers become such types of personalities that can handle all situations without any fear. Therefore, it becomes the main theme of leadership and its effectiveness. Beachum and Dentith (2004) are of the view that different approaches regarding the leaders' skills and styles highlight the way of encouraging the workers/employees and followers. It pays attention to the personification of workers' opinion, ideologies, beliefs and thinking. About the effective learning Bloom, Hastings, and Madaus (1971) describe that these factors are related with the learners' thoughts, motivational level, feeling, and other levels for recognizing their course of studies. The motivational level is the power and courage of learners for achieving knowledge, skills and their academic achievements for performing their all activities in proper manner. Literature explains the fact that students' learning depends upon teachers' leadership styles. Yu, Leithwood, and Jantzi (2002) point out that supervisor who exhibits this style of leadership can achieve lot of positive outcomes regarding the work environment and regarding the workers' conditions like their satisfaction about their designation, their job fulfillment, job effectiveness, and also show advanced levels of associational obligations. As Duke (2004) describes and points out in his critical analysis that these leaders have some main and very important qualities that differentiate them from the ordinary leaders. No doubt that Dukes' (2004) concept forms a direct relationship between the performance and the leaders' style but our review of the literature provides us with various research studies that add emphasis to the indirect relationship between outcomes and leadership styles. There are different studies that explore the relationship of different factors in different environment. As Terborg (1995) examined the effectiveness of this style of leaders on their fellows' behavior and learners' overall actions in the specific environment. 


\section{Leadership in Public and Private Sector}

Literature defines leadership as an important element in all types of organizations whether they are in public or in the private sector. We can find some major distinction among both types of institutions, their leadership style plus their work conditions.

In defining such differences, Wirick (2009) described the main difference between public and private sector organizations as being in the forms of ownership. As we know that public sector organizations are owned and operated by government, whereas private sector organizations are not part of the government and they generally are owned by private parties. Kassel (2010), Sims (2010) and several other researchers have also expressed the same views by declaring that main division is the type of supervision among both of the organizations because ownership changes the style of their leadership. They also emphasize that the basic aim of organizations operating in private sector is earning maximization. In the words of Gallos (2008) "we do not mislead as a result of generous activities of non-government organizations regarding their objectives plus their persistence that the basic aim of their activities and performances is helping the basic cause of such organizations that is earning maximization”. For achieving the primary objective leader motivates his employees and utilizes all techniques and styles.

Sims (2010), while defining the mutual difference between governmental and non-governmental sector observed that the purpose of governmental organizations is to engage and work for the wellbeing of citizens with different aspects and styles according to the demand of their organization e.g. the basic purpose of government educational institutions is providing educational facilities at national level inside the state and health organizations provide health facilities.

\section{Methodology}

Research Design: This research is descriptive in nature. The data was collected by visiting the institutions personally.

Participants: The participants of the study were both students and teachers of $12^{\text {th }}$ grade from public and private colleges, registered and affiliated with Federal Board of Intermediate and Secondary Education 
Islamabad. Total 22 male and 20 female colleges, affiliated with Federal Board of Intermediate and Secondary Education Islamabad, were selected through cluster sampling technique. The sample of 605 students and 600 teachers was taken and their opinions about the effectiveness of teachers' transformational leadership styles on students' academic achievement were recorded. For data collection research instruments were administered to subjects with the permission of the principal of each college.

Instruments: In order to draw valid conclusions from research, reliable and valid tools must be used for measuring the variables, so in this study the standardized test was used, as the main aim of research was to compare the effectiveness of this style of teachers' with the academic achievement of students. For this the instrument Multifactor Leadership Questionnaires (MLQ 5x-short) $3^{\text {rd }}$ edition developed by Bruce and Bernard (1994) was used. The basic philosophy and test material underlying this instrument is attention that has been given to charisma and inspirational leadership in prior literature (Antonakis, Avolio \& Sivasubramaniam, 2003; Bass \& Avolio, 1994). The purpose of this is, to review the soundness and effectiveness of this style of leadership with the help of general measurements. This questionnaire consists of two parts: the Self Rating Form, where leader/teacher rate themselves as leaders, and the Rater Form, where followers/students rate their leaders/teachers. Both parts of the above mentioned instrument were in English and not translated in Urdu because of easy and understandable language for students and teachers alike (used after seeking approval from experts).

Reliability and Validity: The researcher held a pilot testing to find out the reliability of both of the instruments. 106 teachers and 115 students were selected for pilot testing. The both parts of the instruments were found reliable.

\section{Data Analysis}

The data collected through the respondents was organized and analyzed through statistical application; t-test for inferential details and results. The analysis is presented in tabular form as below. 
Nighat \& Sufiana

Table 1

Mean difference of teachers' views about Transformational Leadership style

\begin{tabular}{ccccccc}
\hline Sector & $\mathbf{N}$ & Mean & SD & $\boldsymbol{t}$-value & $\boldsymbol{d f}$ & $\boldsymbol{p}$-value \\
\hline Public & 249 & 34.49 & 7.541 & & & \\
& & & & -1.041 & 597 & 0.298 \\
Private & 350 & 35.12 & 7.095 & & & \\
\hline
\end{tabular}

Table 1 shows basic division on the score of transformational leadership style between both sectors. The result explains that the mean of public sector was 34.49 and private was 35.12. This mean difference; i.e. 0.63 and $\mathrm{P}>.05$ is no significant statistically. Therefore, our null hypothesis is accepted because teachers from both sectors were same in their opinion about transformational leadership style of teachers. This explains the level of awareness of teachers from both sectors.

Table 2

Mean difference of teachers' views about idealized influence

\begin{tabular}{ccccccc}
\hline Sector & $\mathbf{N}$ & Mean & SD & $\boldsymbol{t}$-value & $\boldsymbol{d} \boldsymbol{f}$ & $\boldsymbol{p}$-value \\
\hline Public & 409 & 13.71 & 3.667 & & & \\
& & & & 0.050 & 598 & 0.960 \\
Private & 191 & 13.70 & 2.944 & & & \\
\hline
\end{tabular}

Table 2 exhibits major division of scores of idealized influence between the both sectors. According to the result the public sectors' mean was 13.71 while the mean of private was 13.70 . The basic division; i.e. 0.01 is statistically non significant as $p>.05$. According to the results there is no major difference of opinions of public and private college teachers about idealized influence.

Table 3

Mean difference of teachers' views about inspirational motivation

\begin{tabular}{ccccccc}
\hline Sector & $\mathbf{N}$ & Mean & SD & $\boldsymbol{t}$-value & $\boldsymbol{d} \boldsymbol{f}$ & $\boldsymbol{p}$-value \\
\hline Public & 409 & 6.76 & 1.821 & & & \\
& & & & -1.298 & 598 & 0.195 \\
Private & 191 & 6.96 & 1.692 & & & \\
\hline
\end{tabular}


Table 3 reveals dissimilarity between scores of Inspirational Motivation in both sectors. The mean of public sector was 6.76 and private was 6.96. This mean difference; i.e. 0.2 is no significant statistically because $\mathrm{p}>.05$. So, the null hypothesis is accepted that teachers from the both sectors were same in their opinions about the inspirational motivation.

Table 4

Mean difference of teachers' opinions about intellectual stimulation

\begin{tabular}{ccccccc}
\hline Sector & $\mathbf{N}$ & Mean & SD & $\boldsymbol{t}$-value & $\boldsymbol{d} \boldsymbol{f}$ & $\boldsymbol{p}$-value \\
\hline Public & 409 & 6.91 & 1.981 & & & \\
& & & & -3.818 & 598 & 0.000 \\
Private & 191 & 7.59 & 2.135 & & & \\
\hline
\end{tabular}

Table 4 presents major division of the score of intellectual stimulation in both sectors. The mean of public sector was 6.91and private was 7.59. The mean score of private was greater than public sector. The basic division is 0.68 and $\mathrm{p}<.05$ that is statistically significant. Therefore, our null hypothesis that the major dissimilarity of both sectors' college teachers about intellectual stimulation is not accepted. It is concluded that intellectually stimulated teachers from public and private colleges have significant difference in opinion.

Table 5

Mean difference of teachers' views about individual considerations

\begin{tabular}{ccccccc}
\hline Sector & $\mathbf{N}$ & Mean & SD & $\boldsymbol{t}$-value & $\boldsymbol{d} \boldsymbol{f}$ & $\boldsymbol{p}$-value \\
\hline Public & 409 & 7.02 & 12.516 & & & \\
& & & & -2.792 & 598 & 0.005 \\
Private & 191 & 7.63 & 2.463 & & & \\
\hline
\end{tabular}

Table 5 explains the major division between the scores of individual considerations between both sectors. Mean of public sector was 7.02 and private was 7.63. The mean score of private was greater than public sector teachers. The dissimilarity i.e. 0.61 which is significant according to statistics because $\mathrm{p}<.05$. Thus, we cannot find any significant dissimilarity in the opinions of both sectors' college teachers and individual consideration is not accepted. It is concluded that about individual considerations, teachers from public and private sectors have difference of opinion. 
Nighat \& Sufiana

Table 6

Correlation between students' academic achievement and their teachers' transformational leadership style mean score

\begin{tabular}{cccccc}
\hline Variables & N & Mean & SD & $\begin{array}{c}\text { Pearson } \\
\text { 'r' }\end{array}$ & $\begin{array}{c}\text { Sig } \\
\text { (2-tailed) }\end{array}$ \\
\hline $\begin{array}{c}\text { Students } \\
\text { Achievement }\end{array}$ & 605 & 3.04 & 1.200 & & \\
$\begin{array}{c}\text { Transformational } \\
\text { Leadership Style }\end{array}$ & 605 & 34.87 & 7.282 & 0.098 & $0.017^{*}$ \\
\hline
\end{tabular}

Table 6 explains value of Pearson ' $r$ ' (0.098) among the student's achievement plus teacher transformational leadership style's mean score, which is important according to the 0.01 level. The result does not show any dissimilarity and relationship among the effectiveness of teachers' transformational leadership style and students' academic achievement.

\section{Results}

The major findings observed from the data analysis were: teachers from the both sectors held same opinions about the inspirational motivation, whereas they have significant difference of opinion about intellectual stimulation, similarly significant dissimilarity in the opinions of college teachers of both sectors regarding individual considerations was not observed and the result does not show any dissimilarity among the effectiveness of teachers' transformational leadership style and students' academic achievement.

\section{Discussion}

It was concluded that public and private sectors' teachers have same opinion about transformational leadership style with the exception of some aspects like intellectual stimulation and individual consideration. These findings are in accordance with our present situation where we cannot find any concept of teacher leadership but this concept is just related with administration. That's why we can observe that our educational administrators do not give any consideration to leadership qualities of the teachers. Therefore, it may be the cause why they are not aware of their leadership role and its effectiveness. This situation brings forth the reality. In consistence with the findings of the studies carried 
out by Dahl \& Lind (1935) and Downs (1967) major differences among both sectors were found out. Bacali (2010) explained some major differences in his studies that narrate morals, organization, lawful structure, relevance demonstrations, aim, civilization plus effectiveness of executive orders. The findings of the current research are also consistent with the findings of Hinea (2008) and in line with results of that of Pollit and Bouckaert (2000) where they illustrated reality about hurdles people in management face like they always have to fight with superb diplomacies, financial and communal issues and technical advancements.

There are some issues like issue of performance and its measurement which is being difficult in public sector because of their multiple goals Van Slyke \& Alexander, 2006). The finding is also consistent with the study of Bacali (2011) who explained that in public sector the administration is scattered, disjoined but has externally stronger impacts so their orders become more difficult like a continues struggle for supporting different investors through their strategies so they do not give any importance to the teachers' leadership. This is the basic reason for increasing the workload on governmental organizations as compared to their other counterparts. In the view of Howell (1997), Bass and Riggio (2006) as compared with non-government organizations this leadership style is not much popular in government organization because they are most of the times under the control of pressure groups like administration wing.

While describing the situation in public sector the researchers Wright and Pandey (2004) explained that government institutions are normally controlled through different pressure groups. According to different researches, it is suggested that commonly the public institutions show just reasonable impact of external management like only for formation and reutilization with growing importance for creativeness, novelty and receptiveness for increasing effectiveness and show understandings for national requirements. There is another problem with public sector that the administration happens to be not very alert and approachable. While in the private sector, administration usually takes initiative and interest. They work hard to change their situation according to the global changes. They want to develop their institution and make it prominent. For this they ensure the development of their students through their teacherleaders. 


\section{Conclusion}

The research result revealed that teachers have no awareness about the effectiveness of teachers' transformational leadership style on students. Therefore it is recommended that College teachers may be made aware about the concept and importance of leadership through professional development training.

Based on the results, the writers present the following recommendations:

1. College teachers of both public and private sector may get training to develop leadership skills.

2. There is a need to raise awareness about idealized influence of teachers through training them about how to promote students' interest in learning.

3. College teachers may be provided training in how to inspire students through their personality charisma and through this inspiration how to motivate students for learning.

4. College teachers might be given training about the importance of team work in achieving individual and organizational goals.

\section{REFERENCES}

Bass, B. M. \& Avolio, B. J. (1998). Improving Organizational Effectiveness through Transformational Leadership, in Leading Organizations: Perspectives for a New Era, edited by G. Hickman. London: Sage Publications Limited: 135-139.

Bass (1978). “Concepts of Leadership

' (Chapter One). Bass \& Stogdill's Handbook of Leadership: Theory Research, \&Managerial Applications (3rd edition).New York: Free Press.

Bass, B.M. \& Riggio, R.E (2006). Transformational leadership. Mahwah, New Jersey 07430: Lawrence Erlbaum Associates, Inc.

Bass, B. M. \& Avolio, B. J. (1998). Improving Organizational Effectiveness through Transformational Leadership, in Leading Organizations: Perspectives for a New Era, edited by G. Hickman. London: Sage Publications Limited: 135-139.

Bass, B. M. (1990). From transactional to transformational leadership: Learning to share the vision. Organizational Dynamics, (Winter): 19-31. 
Bass \& Bernard M (1997) "The Ethics of Transformational Leadership." In Kellogg Leadership Studies Project, Transformational Leadership Working Papers Transformational Leadership Working Papers, The James MacGregor Burns Academy of Leadership, 1997.

Beachum, F. and Dentith, A.M. (2004) 'Teacher Leaders Creating Cultures of School Renewal and Transformation', The Education Forum 68(3): 27686.

Bloom, Hasting \& Madaus. (1971). Handbook on Formative and Summative Evaluation of Student Learning. New York: MacGraw-Hill.

Burns, J. M. (1978). Leadership. New York: Harper \& Row.

Danielle Charbonneau (2004) Influence tactics and perceptions of transformational Leadership. Leadership \& Organization Development Journal, Vol. 25 (7): 565-576.

Chory, McCroskey (1990). The relationship between teacher management communication style and affective learning. Thousand Oaks, CA: Corwin Press, Inc.

Duke (2004). What do we know about teacher leadership? Findings from two decades of scholarship. Review of educational research, 74(3), 255-316.

Griffith, J. (2004). Relation of principal transformational leadership to school staff job satisfaction, staff turnover, and school performance. Journal of Educational Administration, 42(3), 333-356.

Ingram, P. D. (1997). Leadership behaviours of principals in inclusive educational settings. Journal of Educational Administration, 35(5), 411-427.

Leithwood et.al (1990) Transformational leadership: How principals can help reform school cultures. School Effectiveness and School Improvement, 1(4), 249-280.

Moore (1927) Voice and choice in Chicago. In Choice und Control in America Education. Vol. II: The Prtrctice of Choice. Decenrrcdization, and School Restructuring (Edited by Clune, W.H. andWitte, J.F.). pp. "IS3-197. New York: The Falmer Press.

McGregor, D. (1960). The human side of enterprise. New York, 21, 166.

Northouse (2007) Leadership, Theory and practice: Sage Publications, pp. 97-100. 
Simić, I. Ž. (1998). Transformational leadership: The key to successful management of transformational organizational changes. Factauniversitatis-series: Economics and Organization, 1(6), 49-55.

Schermerhorn (2008). Management: 3rd Asia-Pacific ed. John Wiley \& Sons Australia, Ltd.

Timothy (2004) Transformational and transactional leadership; A meta-analytic test of their relative validity, (2004) Journal of Applied Psychology, 89, p. 755-75.

Yuen, P. Y., \& Cheng, Y. C. (2000). Leadership for teachers' action learning. International Journal of Educational Management, 14(5), 198-209.

Wahlstrom (1993) Adoption revisited: Decision-making and school district policy. In S. B. Bacharach and R. T. Ogawa (Eds.), Advances in research and theories of school management and educational policy, Vol. 2, pp. 61-119.

Wright \& Pandey (2004). A short history of progress. Toronto, ON: House of Anansi Press.

Received on: October $5^{\text {th }} 2014$

Revised on: October $16^{\text {th }} 2015$

Accepted on: November $2^{\text {nd }} 2015$ 